\title{
PATZ1 wt Allele
}

National Cancer Institute

\section{Source}

National Cancer Institute. PATZ1 wt Allele. NCI Thesaurus. Code C97877.

Human PATZ1 wild-type allele is located in the vicinity of $22 \mathrm{q} 12.2$ and is approximately 20 $\mathrm{kb}$ in length. This allele, which encodes POZ-, AT hook-, and zinc finger-containing protein

1 , plays a role in the negative regulation of transcription. A chromosomal inversion $\operatorname{inv}(22)(q 12 q 12)$ of this gene and the EWSR1 gene is associated with Ewing sarcoma. 